\title{
CRYSTALLINE PEPSIN
}

\author{
I. Isolation and Tests of Purity
}

BY JOHN H. NORTHROP

(From the Laboratories of The Rockefellex Institute for Medical Research, Princeton, $N . J$.

(Accepted for publication, May 9, 1930)

I

INTRODUCTION

Enzymes are in many respects connecting links between living and inanimate matter since their action is analogous to inorganic catalysts, although the enzymes themselves are found only in living organisms. As catalysts they increase the rate of one or more specific reactions and so act as directive agents for the reactions occurring in the organism. This directive property is undoubtedly essential for the existence of living cells. As a consequence of these properties the study of enzymes has been of interest to both chemists and biologists and has resulted in a great increase in the knowledge of their mode of action. The results of attempts to isolate the enzymes in pure form, however, have been singularly unsuccessful. There seems to be no convincing evidence that any enzyme has been obtained in the pure state; and only one, the urease described by Sumner (1), has been previously obtained in crystalline form. A number of methods have been found which allow the activity of an enzyme preparation to be increased almost indefinitely; at the same time, however, the preparation becomes more unstable and eventually the activity becomes lost.

In practically all the work the assumption has been made either explicitly or otherwise that the activity was a measure of the purity of the preparation and that any increase in activity was due to an increase in purity. This is not necessarily true. If the enzymes are analogous to inorganic catalysts then it is quite possible that the activity depends on the physical arrangement of the molecules or atoms (2). Evidence for this relation between the physical state and 
the activity was found by Fodor (3) in the case of the proteolytic enzymes of yeast, and by Kuhn and Wasserman (4) in the case of hemin. It is possible, on the other hand, that enzymes in general are of the type of hemoglobin (which might be considered an enzyme), and that they consist of an active group combined with an inert group. It might be possible under certain conditions to attach many more active groups to the inert group and so increase the activity above that of the original compound. Either of the above ideas would account for the well-known fact that crude preparations are much more stable than purified material and that the rate of inactivation of enzyme solutions practically always shows evidence of a mixture of stable and unstable forms $(5,6)$.

There is some reason to think, therefore, that enzymes exist in a more stable form for either physical or chemical reasons, and in view of the uniformly negative results which have been obtained in attempting to isolate the most active preparations it seemed advisable in attempting the isolation of pepsin to study the more stable as well as the most active fraction.

II

PRELIMINARY EXPERTMENTS

A number of methods have been proposed for the purification of pepsin, such as precipitation with safranin (7), etc., fractionation by various adsorbents, and precipitation by dialysis from acid solution (Pekelharing (8)). These and a number of other methods were tried and more or less active preparations obtained. The results with Pekelharing's method seemed the most encouraging, however, since the loss of activity was less and there was some indication that a constant activity was reached. This result has been reported by Pekelharing and also by Fenger, Andrew and Ralston (9) using a similar method. It was found, however, that the dialysis could be dispensed with and the process made more rapid and efficient by solution with alkali and subsequent precipitation with acid, after a preliminary precipitation with half saturated $\mathrm{MgSO}_{4}$ or $\left(\mathrm{NH}_{4}\right)_{2} \mathrm{SO}_{4}$. The amorphous material so obtained contains about half the activity present in the original material and is 3 to 6 times as active as measured by the liquefaction of gelatin and about 5 times as active as measured by the 
digestion of casein or by the rennet action on milk. ${ }^{1}$ Repetition of this procedure gave products of increasing activity as measured by the liquefaction of gelatin, and apparently this activity could be increased indefinitely. Several samples were obtained which were 100 times as active as the original preparation. They were also more unstable, so that each succeeding precipitation was accompanied by a larger and larger percentage loss until finally no more active material remained. This has been the fate of all previous attempts to isolate the most active fraction of a number of enzymes. When the activity of the various fractions was determined by the rate of hydrolysis of casein or by the rennct action on milk, howcver, it was found that the activity increased until it reached about 5 times that of the crude preparation

1 Determination of Activity. - The rate of digestion of proteins by pepsin may be followed by determining the increase in carboxyl groups or amino nitrogen, or by the decrease in protein nitrogen or by the changes in viscosity. The increase in carboxyl groups probably represents the best measure of the progress of the reaction and has been used as the basis of the activity units used in this paper.

The most widely used unit of enzyme activity in general is that suggested by Eulcr (16) and is equal to the velocity constant of the reaction divided by the grams of enzyme. Theoretically this is undoubtedly correct since the activity of a catalyst can be expressed only as a veJocity constant. Many enzymes do not give a velocity constant independent of the substrate concentration but instead the velocity constant decreases as the substrate concentration increases. This is especially true of pepsin and in addition the reaction does not follow any simple reaction rate. The end point of the reaction, which must be known in order to calculate the velocity constant, is also very diflicult to determine. It is not practical therefore to use the velocity constant as a measure of activity of pcpsin.

The activity of pepsin may conveniently be defined as the milliequivalents of carboxyl groups liberated per mole or gram of enzyme per minute at $35.5^{\circ} \mathrm{C}$, optimum $\mathrm{pH}$, and 5 per cent substratc concentration. Theoretically it would be better to use that substrate concentration al which the rate of reaction is a maximum, but experimentally this is difficult, owing to the high viscosity of such concentrated solutions. The enzyme concentration used should be in the range in which the activity is proportional to the enzyme concentration. In order to determine the activity in this way the rate of hydrolysis of casein, gelatin, edestin, and denatured egg albumin at $\mathrm{pH} 2.0$ to 2.5 , was determince by means of the increase in formol titration (19).

The following abbreviations are used in this paper:

$\mathrm{I}^{\prime} \mathrm{U}=$ proteolytic units - milliequivalents carboxyl groups per minute.

$[\mathrm{PU}]_{\mathrm{gm} .}=$ " " "per gram.

$[\mathrm{PU}]_{\mathrm{EM} . \mathrm{F}}^{\text {cas. }}=$ " “ " " " as determined by cas. F. method, etc. 
and then remained constant instead of increasing as did the gelatin liquefying power. This was the result reported by Pekelharing and also by Fenger, $\Lambda$ ndrew and Ralston. This material appeared to be protcin, as previous workers had found, and was reasonably stable. Efforts were therefore made to isolate this protein in crystalline form.

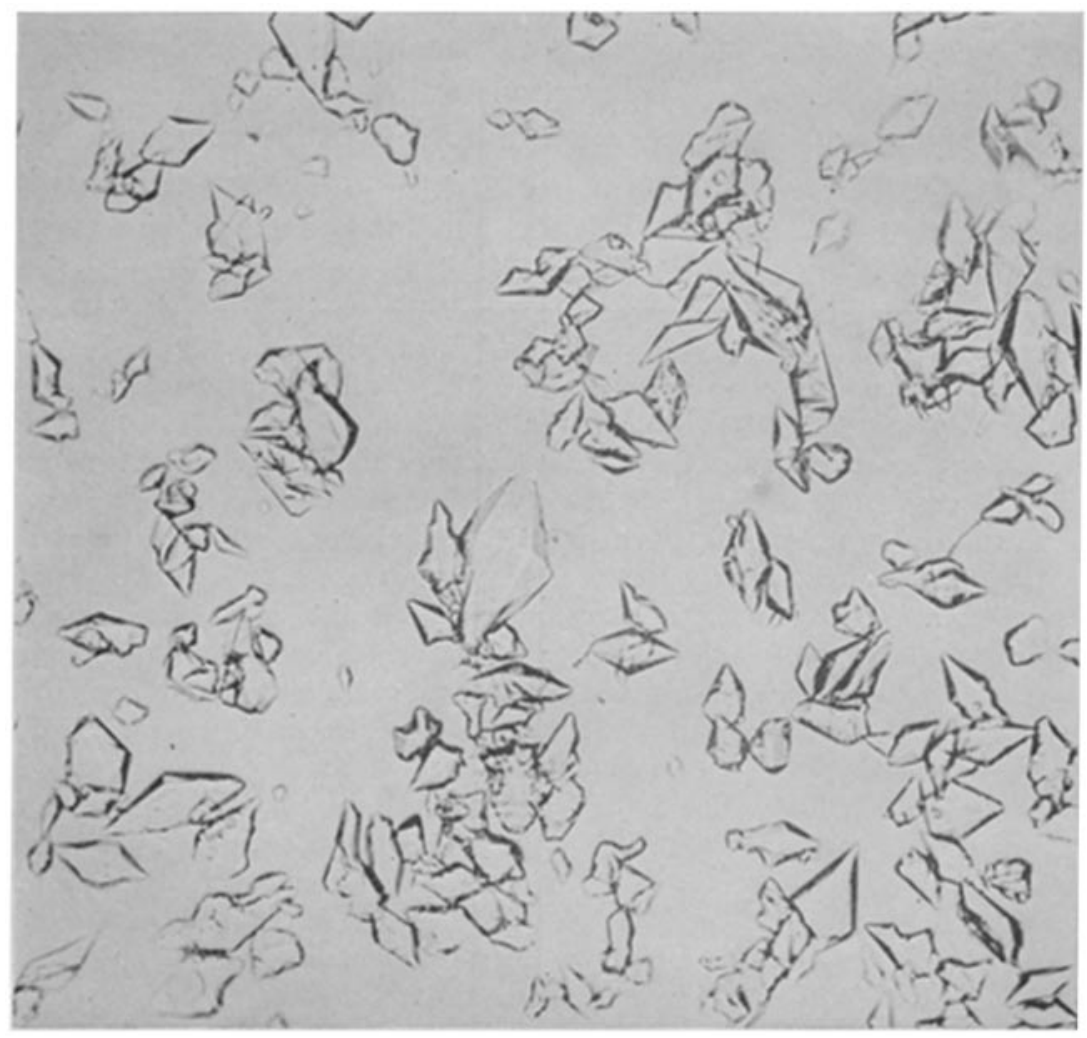

FIG. 1. Crystalline pepsin

III

\section{Isolation of the Crystalline Ensyme}

It was noticed that the precipitate which formed in the dialyzing sac when the procedure of Pekelharing was followed appeared in more or less granular form and filtered rather easily, as though it were on the verge of crystallization. This precipitate dissolved on warming the 
suspension and it was eventually found that it could be induced to crystallize by warming to $45^{\circ} \mathrm{C}$., filtering, and allowing the filtrate to cool slowly. The crystals so obtained were regular hexahedra and showed a tendency to grow in clusters, especially when appearing from more acid solutions. They are remarkably similar to the urease crystals pictured by Sumner and differ only in that they have a hexagonal base while the urease has an octagonal base. On one occasion a few crystals with truncated pyramids were obtained. They had the same activity and optical activity as the usual form. The crystals showed positive double refraction and were optically active in solution. They possessed proteolytic activity, when dissolved, equivalent to 5 times that of the U.S.P. 1 to 10,000 pepsin as measured by hydrolysis of casein, and 2.5 times as measured by the liquefaction of gelatin.

Improved Method for the Preparation of the Crystals.-The isolation of the crystals in bulk by the above method was difficult owing to the dialysis. It was found that this could be avoided and the purification carried out as outlined above for the amorphous preparations except that the acid precipitate was dissolved at $45^{\circ} \mathrm{C}$. in concentrated solution. On inoculation, this solution set to a solid paste of crystals. The following is an outline of the method as finally developed.

IV

General Properties and Analysis of the Crystals

The material prepared in this way has the general properties of a protein. It is coagulated by heat, precipitated by saturation of the solution with $\mathrm{MgSO}_{4}$ or $\left(\mathrm{NH}_{4}\right)_{2} \mathrm{SO}_{4}$ and gives a strongly positive xanthoproteic test. The MiHon test is negative. The crude material contains a large amount of yellowish pigment which is removed with difficulty. It may be largely removed by reprecipitation with $\mathrm{MgSO}_{4}$ and becomes less as the material is recrystallized. All the preparations however, give a slightly yellowish solution when dissolved although the dry crystals are pure white after several crystallizations. There is no relation between the activity and the color. Analysis of the material gave the results shown in Table II.

The crystals are difficult to dissolve after drying and are best kept under saturated $\mathrm{MgSO}_{4}$ at $5^{\circ} \mathrm{C}$. They are instantly inactivated by alkali in solution and lose activity slowly in acid solutions. The 
TABLE I

Preparation of Crystaline Pepsin

\begin{tabular}{|c|c|c|c|c|}
\hline \multirow{2}{*}{ Procedure } & \multicolumn{4}{|c|}{$\begin{array}{l}\text { Activity per gm. dry weight } \\
\text { Method }\end{array}$} \\
\hline & Gel. V. & Cas. $S$. & | Rennet & E. A. \\
\hline 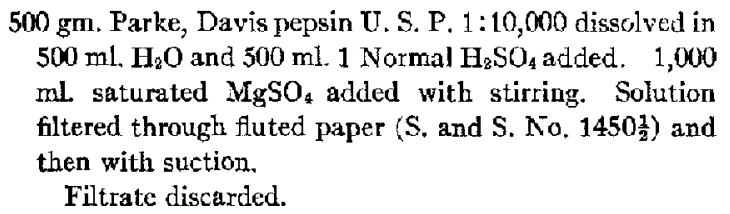 & 0.075 & 2.5 & 2.5 & 4.5 \\
\hline $\begin{array}{l}\text { Precipitate 1. Wash twice with equal volume } \frac{2}{8} \text { saturated } \\
\mathrm{MgSO}_{4} \text {, filter with suction. } \\
\text { Filtrate discarded. }\end{array}$ & & & & \\
\hline $\begin{array}{l}\text { Precipitate 2. Stir with water to thick paste and } \mathrm{M} / 2 \\
\mathrm{NaOH} \text { run in until complete solution. (Great care must } \\
\text { be taken to avoid local excess of } \mathrm{NaOH} \text {. pH never more } \\
\text { than } 5.0 \text {.) } \\
\mathrm{M} / 2 \mathrm{H}_{2} \mathrm{SO}_{4} \text { added with stirring until heavy precipitate } \\
\text { forms, (pH about } 3.0), 3 \text { to } 6 \mathrm{hrs} \text {. at } 8^{\circ} \mathrm{C} \text {, filter with } \\
\text { suction. } \\
\text { Filtrate discarded. }\end{array}$ & .15 & 7.5 & 7.5 & 7.0 \\
\hline $\begin{array}{l}\text { Precipitate 3. Stir with } \mathrm{H}_{2} \mathrm{O} \text { to thick paste at } 45^{\circ} \mathrm{C} \text {., } 3 / 2 \\
\text { NaOH added carefully until precipitate dissolves, } \\
\text { (filter if cloudy and discard precipitate). Beaker con- } \\
\text { taining filtrate placed in a vessel containing about } 4 \text { liters } \\
\text { of } \mathrm{H}_{2} \mathrm{O} \text { at } 45^{\circ} \mathrm{C} \text {., inoculated and allowed to cool slowly, } \\
\text { cooling should require } 3 \text { to } 4 \text { hrs. and heavy crystalline } \\
\text { precipitate should form at about } 30 \text { to } 35^{\circ} \mathrm{C} \text {. Solution } \\
\text { kept at } 20^{\circ} \mathrm{C} \text {. for } 24 \text { hours. Thick crystalline paste, } \\
\text { filter with suction. }\end{array}$ & .15 & 10.0 & 10.0 & 8.0 \\
\hline $\begin{array}{l}\text { Precipitate } 4 \text {. Wash with small amount of cold } \mathrm{H}_{2} \mathrm{O} \text { and } \\
\text { then with } \frac{1}{2} \text { saturated } \mathrm{MgSO}_{4} \text { and store under saturated } \\
\mathrm{MgSO}_{4} \text { at } 5^{\circ} \mathrm{C} \text {. } \\
\text { Filtrate. } \mathrm{M}_{2} / 2 \mathrm{H}_{2} \mathrm{SO}_{4} \text { added to } \mathrm{pH} 3.0 \text {, amorphous precipi- } \\
\text { tate filtered off and treat as Precipitate } 3 \text {. }\end{array}$ & .17 & 14.0 & {$[14.0]$} & 9.0 \\
\hline
\end{tabular}

\section{Recrystallization}

Method 1. Crystalline paste filtered with suction on large funnel so as to form a thin layer of crystals and washed 3 times with cold $\mathrm{m} / 500 \mathrm{HCl}$. Filter cake stirred to a paste with $\frac{1}{2}$ its weight of water, the suspension warmed to $45^{\circ} \mathrm{C}$. and $\mathrm{M} / 2 \mathrm{NaOH}$ run in slowly with constant stirring until the precipitate dissolves $(\mathrm{pH}<5.0) . \quad \mathrm{M} / 2 \mathrm{H}_{2} \mathrm{SO}_{4}$ is then run in until the solution is faintly turbid, a few crystals added and the solution allowed to cool slowly as before. A heavy crop of crystals should separate in about 24 hrs. The suspension is then warmed to $45^{\circ} \mathrm{C}$. again and more $\mathrm{H}_{2} \mathrm{SO}_{z}$ added until the $\mathrm{pH}$ of the suspension is about 3.0. It is then allowed to cool slowly again, and filtered after $24 \mathrm{hrs}$. The crystals may be washed with $\mathrm{M} / 500 \mathrm{HCl}$ untit free of $\mathrm{SO}_{4}$.

Ammonium sulfate may be used in place of $\mathrm{MgSO}_{4}$. Sodium acetate may be used in place of sodium hydroxide.

Method 2. Crystals dissolved with NaOH and treated as described for Precipitate 2. 
inactivated material is digested by the remaining active material and a large amount of tyrosin crystallizes out. This process also occurs slowly in the ice box so that the crystals on standing become mixed with nonprotein material that is not precipitated by salt nor by heat. The crystals can be freed from this soluble material by thorough washing with $\mathrm{H}_{2} \mathrm{O}$ or by recrystallization. When freshly prepared in this way 98 to 99 per cent of the nitrogen is precipitated from solution by heating rapidly to boiling at $\mathrm{pH} 3$ with sulfuric acid and $\mathrm{Na}_{2}$ $\mathrm{SO}_{4}$, by saturation with $\mathrm{MgSO}_{4}$ or $\left(\mathrm{NH}_{4}\right)_{2} \mathrm{SO}_{4}$, by the addition of alkali

TABLE II

Analysis. Dried at $60^{\circ}$ in vacuo for 24 IIrs.

\begin{tabular}{|c|c|c|c|c|c|c|c|c|c|c|}
\hline Metbod.. & Dumas & $\mid \begin{array}{c}\text { Kicl-1- } \\
\text { cahl }\end{array}$ & $\mid \begin{array}{c}\text { Yan } \\
\text { Slyze }\end{array}$ & & & & & & & $\mid \begin{array}{l}\text { Precipita- } \\
\text { tian with } \\
\mathrm{BaCl}_{2}\end{array}$ \\
\hline & $\underset{N}{\text { Total }}$ & Total & $\frac{\operatorname{Amino}}{\mathrm{N}}$ & C & $\mathbf{H}$ & $\mathrm{Cl}$ & $\mathbf{S}$ & $\mathbf{P}$ & Ash & $\mathrm{SO}=4$ \\
\hline Per cent dry weight & $\begin{array}{l}15.5 \\
15.3\end{array}$ & $\begin{array}{ll}15 & .15 \\
15 & .30\end{array}$ & 0.80 & $\begin{array}{l}52.3 \\
52.6\end{array}$ & $\begin{array}{l}6.66 \\
6.64 \\
6.70\end{array}$ & $\begin{array}{r}0.23 \\
.20\end{array}$ & $\begin{array}{r}0.88 \\
.82\end{array}$ & 0.078 & $\begin{array}{r}0.40 \\
.55\end{array}$ & 0 \\
\hline
\end{tabular}

TABLE III

Activity and Composition of Various Preparations of Pepsin, Crystallized Once

\begin{tabular}{|c|c|c|c|c|c|c|c|}
\hline Preparation.................... & 1 & 2 & $3-5$ & $5-10$ & $10-12$ & $12-20$ & 22 \\
\hline$[\mathrm{PU}]_{\mathrm{gm} .}^{\text {gel. }} . \ldots \ldots \ldots \ldots \ldots$ & 0.17 & 0.16 & 0.18 & 0.154 & 0.16 & 0.14 & 0.17 \\
\hline $\begin{array}{l}\text { Per cent } N \ldots \ldots \ldots \ldots \ldots \\
{[\alpha]_{\mathrm{D}}^{22^{2}} \text { pH } 4.5 \ldots \ldots \ldots \ldots}\end{array}$ & $\begin{array}{r}15.2 \\
-70\end{array}$ & $\begin{array}{c}15,1 \\
-72\end{array}$ & $\begin{array}{c}15.1 \\
-74\end{array}$ & \begin{tabular}{|l|}
15.3 \\
-73
\end{tabular} & $\begin{array}{c}15.2 \\
-74\end{array}$ & $\begin{array}{r}15.0 \\
-71\end{array}$ & $\begin{array}{l}15.1 \\
-70\end{array}$ \\
\hline
\end{tabular}

and subsequent neutralization, or by heating with 10 per cent trichloracetic acid.

Constant Activity of Various Preparations.-About $2 \mathrm{~kg}$. of the crystals have been prepared from six different lots of the commercial preparation during the course of this work and have all had the same percentage of nitrogen and the same activity within the experimental error. A summary of these properties of the various preparations is given in Table III. The preparations in some cases were combined at the final crystallization. 
The relative activity with various substrates and various methods is shown in Table IV. The figures are the average of 6 to 10 determinations with different enzyme preparations. All crystalline preparations tested yielded the same result with these methods, but amorphous preparations frequently gave much higher activity as measured by gelatin hydrolysis and lower activity as measured by egg albumin,

TABLE IV

Activity of Various Ensyme Preparations

\begin{tabular}{|c|c|c|c|c|}
\hline Enzyme & Substrate & Metbod & $\begin{array}{l}\text { Activity. } \\
\text { Milliequivalents } \\
\text { per Em. per } \\
\text { min. = } \\
\text { [PU! }]_{g m .}\end{array}$ & $\begin{array}{l}\text { Milliequivalents } \\
\text { per nilimole } \\
\text { or equivalents } \\
\text { pet mole per } \\
\text { min. } \\
\text { [PU] } \\
\text { mole }\end{array}$ \\
\hline \multirow[t]{4}{*}{ Crystalline pepsin } & Casein & $\begin{array}{l}\text { Formol } \\
\text { Solution } \\
\text { Rennet action }\end{array}$ & $\begin{array}{l}14 \pm 0.5 \\
{[14]} \\
{[14]}\end{array}$ & 500 \\
\hline & Gelatin & $\begin{array}{l}\text { Formol } \\
\text { Viscosity }\end{array}$ & $\begin{array}{l}.17 \pm 1 \\
{[.17]}\end{array}$ & 6 \\
\hline & Edestin & Formol & $28 \pm .8$ & 1,000 \\
\hline & Egg albumin & Formol & $9 \pm .5$ & 320 \\
\hline \multirow[t]{3}{*}{ U.S.P. pepsin 1:10,000 } & Casein & $\begin{array}{l}\text { Formol } \\
\text { Solution } \\
\text { Rennet action }\end{array}$ & $\begin{array}{c}2.5 \\
{[2.5]} \\
{[2.5]}\end{array}$ & \\
\hline & Gelatin & $\begin{array}{l}\text { Formol } \\
\text { Viscosity }\end{array}$ & $\begin{array}{c}.075 \\
{[.075]}\end{array}$ & \\
\hline & Egg albumin & Formol & 4.5 & \\
\hline
\end{tabular}

while the activity as measured by casein hydrolysis remained constant. On recrystallization of these abnormal amorphous precipitates the activity always returned to the characteristic value for the crystalline material, shown in the table.

The activity compared to other enzymes is less than that reported by Sumner for urease, on a weight basis, and much less than for several other enzymes, but comparison should be made on the basis of activity per mole rather than per gram of enzyme. 
$\mathrm{V}$

Evidence Concerning the Purity of the Crystalline Material

Constant Activity and Composition on Repeated Crystallization.The work reported above shows that a crystalline protein having proteolytic activity may be obtained in quantity from commercial preparations of pepsin. The question of interest is whether this proteolytic activity is a property of the protein molecule or of another molecular species associated with the protein. The usual criterion for the purity of a substance is constant composition and properties after repeated recrystallization. Unfortunately in the case of proteins the

TABLE V

Summary of Recrystallized Pepsin

\begin{tabular}{|c|c|c|c|c|c|c|c|}
\hline $\begin{array}{l}\text { Crystallization } \\
\text { Na. and colar }\end{array}$ & $\begin{array}{l}\text { Quantity } \\
\text { of } \\
\text { crystals }\end{array}$ & [PU] & {$[\mathrm{pU}]_{\mathrm{gm} .}^{\text {cas. } \mathbf{S} .}$} & $\mathbf{N}$ & $\mathbf{P}$ & $\begin{array}{c}{[\alpha]_{\mathrm{D}}^{22^{\circ}}} \\
\mathrm{pH} 5.0\end{array}$ & $\begin{array}{l}\text { Formal } \\
\text { per gm. }\end{array}$ \\
\hline & $\mathrm{gm}$ & & & per cent & per cend & & $\stackrel{m a O H}{\mathrm{NaOH}}$ \\
\hline 1. Dark brown. . & 50 & 0.18 & 14.0 & 14.85 & 0.078 & -70 & 14.0 \\
\hline 2. Brown....... & 22 & .17 & 14.5 & 15.0 & .080 & -70 & 12.5 \\
\hline 3. Yellowish.......... & 15 & .15 & 15.0 & 15.14 & .075 & -68 & 12.5 \\
\hline 4. Slightly yellow fine & & & & & & & 110 \\
\hline 5. Nearly white... & 9 & .16 & & & .076 & $\begin{array}{l}-67.6 \\
-68\end{array}$ & $\begin{array}{l}11.0 \\
110\end{array}$ \\
\hline $\begin{array}{l}\text { 5. Nearly white... } \\
6, \text { " " } \ldots\end{array}$ & $\begin{array}{l}5 \\
3\end{array}$ & $\begin{array}{l}.16 \\
.14\end{array}$ & $\begin{array}{l}14.8 \\
14.5\end{array}$ & 15.13 & $\begin{array}{l}.077 \\
.073\end{array}$ & $\begin{array}{l}-68 \\
-72\end{array}$ & $\begin{array}{l}11.0 \\
11.0\end{array}$ \\
\hline 7. 7. $\quad$ " $\ldots \ldots$ & .5 & .17 & 15.0 & 15.15 & .080 & -72 & 12.0 \\
\hline Original preparation.... & & .075 & 2.5 & & & & \\
\hline
\end{tabular}

melting point, which is the most sensitive test of purity, cannot be used since proteins decompose before melting. Of the other properties the proteolytic activity, optical rotation, and percentage of nitrogen and of phosphorus were considered the most significant and these properties were determined on preparations obtained from a series of seven successive crystallizations. A summary of the results of this experiment is shown in Table $\mathrm{V}$. There is no perceptible drift in any of the properties determined and therefore no indication that the material can ever be separated into fractions by crystallization under these conditions. This shows that the composition of the crystals is independent of the concentration and quantity of the solution from which they are formed. 
Several systems could give this result (10). (1) A mixture of two or more substances present in amounts which are proportional to their solubilities. (2) A solid solution of such composition as to have a minimum solubility. This would correspond to a constant boiling point mixture of miscible liquids. (3) A solid solution of two or more substances having nearly the same solubility. (4) A pure substance.

The various possibilities noted above all depend on some definite relation between the composition of the mixture and the solubilities of the hypothetical components. If this relation were changed, the composition would be changed (except in the case of allotropic modifications). The passibility of such a relation would be greatly reduced if the recrystallization were carried out in a number of different solvents in which the solubility was different. It is quite possible that a mixture of constant composition might be obtained from one solvent just as constant boiling mixtures are frequently found, but it would be expected that the compasition of the mixture would vary with different solvents just as the comprosition of constant boiling mixtures varies with the pressure. If it could be shown therefore that the material retained its constant proteolytic power and composition after recrystallization from a number of different solvents, it would be excellent proof that it was a pure substance. Unfortunately, however, it is not possible to crystallize the material from a series of solvents, but the same result may be obtained by studying the solubility in several solvents.

Results of the Solubility Determinations.-The values for the solubility obtained with different amounts of precipitate in various solvents are shown graphically ${ }^{2}$ in Figs. 2 to 6 . Since the solubility is found to be independent of the amount of precipitate this procedure does not affect the shape of the curve. The soluble nitrogen per milliliter of solution, the proteolytic activity per milliliter of solution as determined by the digestion of casein or gelatin ([PU $]_{\mathrm{ml}}$.) and the optical rotation of the solution in a $1 \mathrm{dm}$. tube are plotted against the total nitrogen content per milliliter of the suspension. The values corresponding to solutions obtained from the undersaturated side are represented by solid dots and those corresponding to solutions obtained from the supersaturated side

\footnotetext{
2 In order to save space the scale representing the total amount of nitrogen per milliliter of suspension has been changed to a logarithmic one in some of the curves after the amount has become large as compared to the amount in solution.
} 
are represented by circles. The solid lines drawn for the curves representing the pepsin per milliliter and the optical activity were calculated on the assumption that the ratio of activity or optical activity to nitrogen was the same in the solution as in the original crystals. That

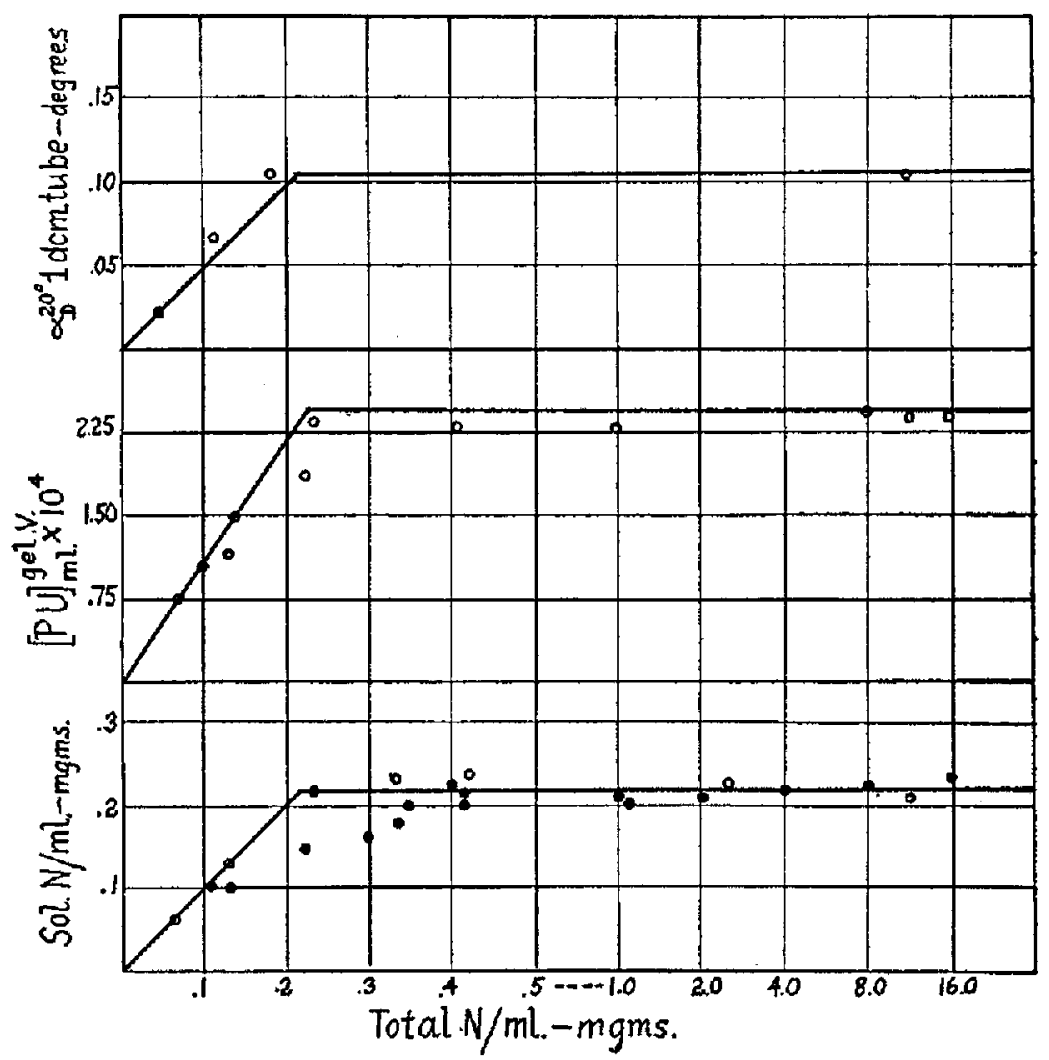

FIG. 2. Solubility of crystalline pepsin in 0.05 acetate and 0.5 saturated magnesium sulfate at $8^{\circ} \mathrm{C}$.

is, 1.15 proteolytic units per gram of nitrogen as measured by the liquefaction of gelatin, 92 proteolytic units per gram of nitrogen as measured by the digestion of casein and a specific rotation per gram of nitrogen of $-460^{\circ}$ as measured at 22 to $24^{\circ} \mathrm{C}$. with the sodium $\mathrm{D}$ line.

The results show: (1) that the solubility is independent of the quan- 
tity of solid present, (2) that the value for the solubility is an equilibrium value since it is the same whether obtained from supersaturated or undersaturated solutions, and (3) the specific proteolytic activity and the specific optical activity are the same for the material present in the solution as for the original material. The material behaves in regard to these determinations as a pure substance and there is no evidence of

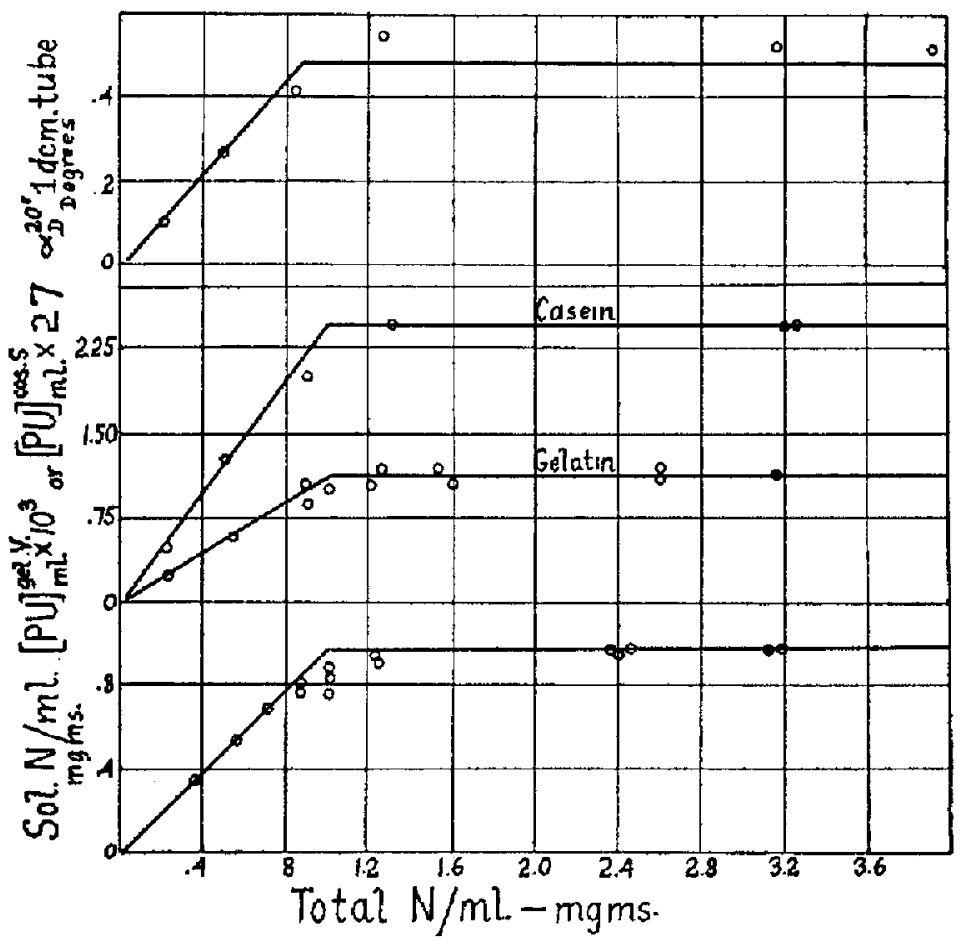

FIG. 3. Solubility of amorphous pepsin in 0.05 acetate and 0.5 saturated magnesium sulfate at $20^{\circ} \mathrm{C}$.

mixture. They show conclusively that the activity cannot be ascribed to the presence of a minute amount of a very highly active material associated with the protein, unless it be further assumed either that this active material has about the same solubility as the protein or that it forms solid solutions with the protein. If the active material were soluble and mixed with the protein the activity per milliliter of solution 
would continue to increase as more and more solid material was added. While if it were present as a relatively insoluble material the activity per milliliter of the supernatant solution would become constant before the solubility of the protein had become constant. The figures show, however, that the proteolytic activity of the liquid becomes constant at the same point at which the concentration of the protein in the solution becomes constant. The only mixture which would behave in this

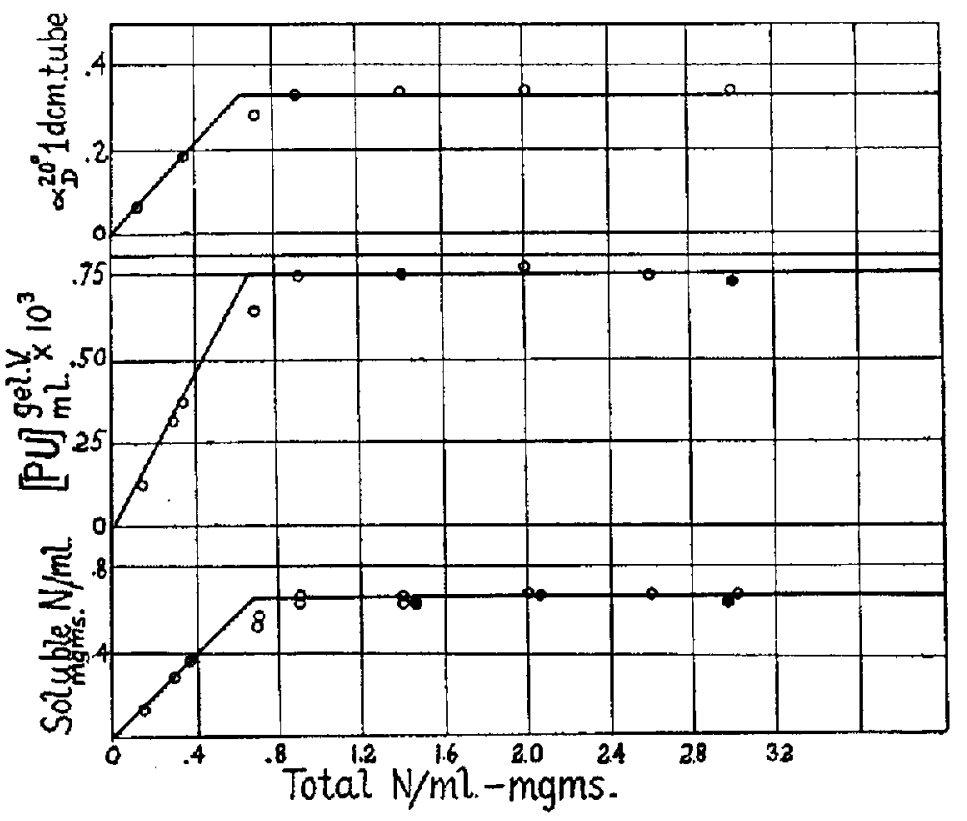

FrG. 4. Solubility of amorphous pepsin in 0.01 acetate and 0.5 saturated magnesium sulfate at $20^{\circ} \mathrm{C}$.

way would be one in which the relative amounts of active material and protein were in almost exact proportion to the relative solubilities of the two substances. This might conceivably be the case in one solvent but the possibility that this relation would hold in several solvents appears so small as to be negligible.

There remains only the possibility that the active material forms a solid solution with the protein and is either present in small amount or has about the same solubility as the protein. If it were present in 
small amount and dissolved in the protein, its presence would not affect the total solubility curve. The ratio of the active material to the protein in the precipitate at the point where the precipitate first

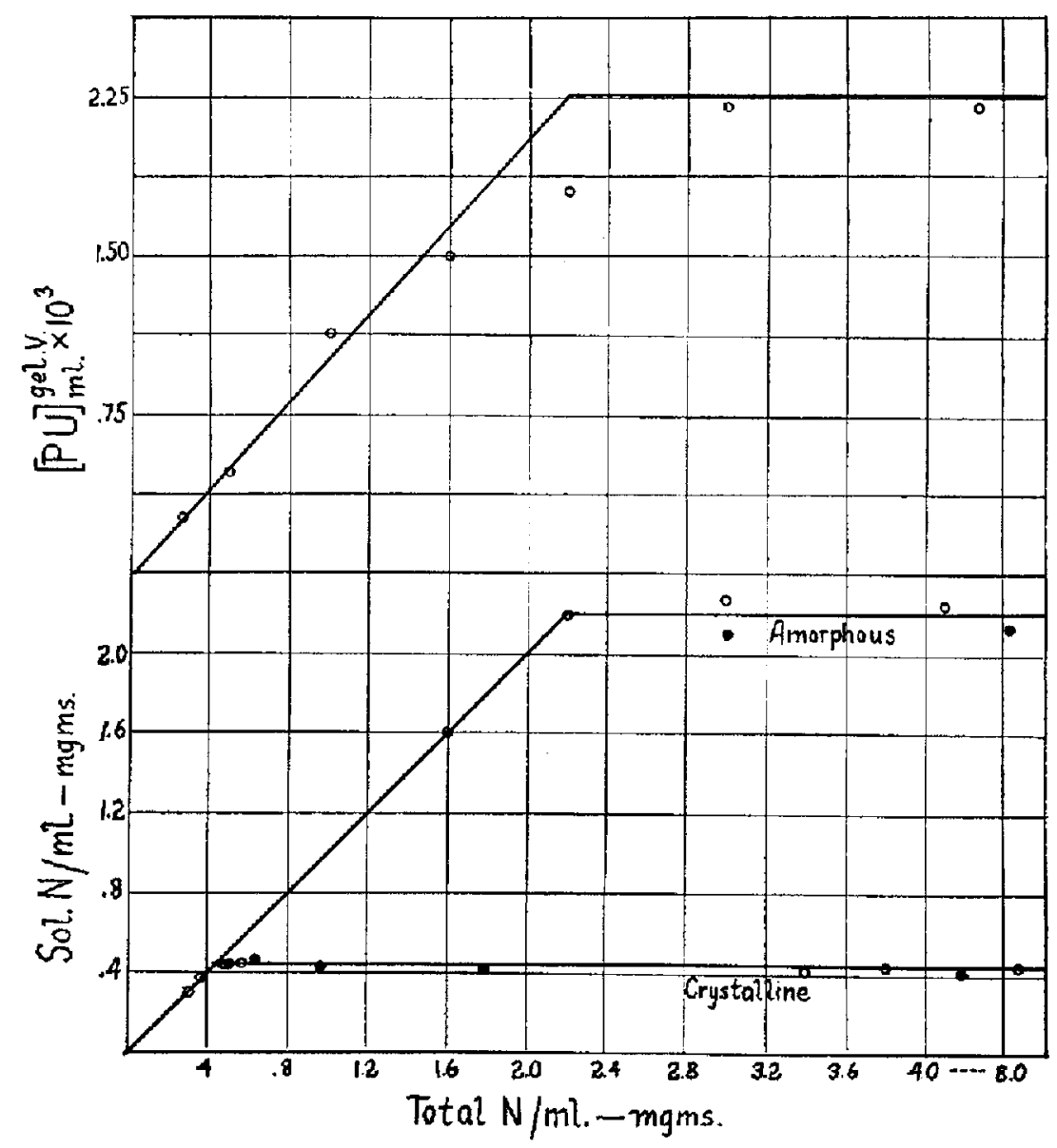

FIG. 5. Solubility of crystalline and amorphous pepsin in 0.055 acetate and 0.444 saturated magnesium sulfate at $20^{\circ} \mathrm{C}$.

appears would differ, however, from the ratio in the original material. The ratio in the solution in that part of the curve where there is a large amount of solid present would also differ from the ratio in the original 
material. The figures show that this latter condition does not occur. The activity per gram of nitragen in the solution in equilibrium with a

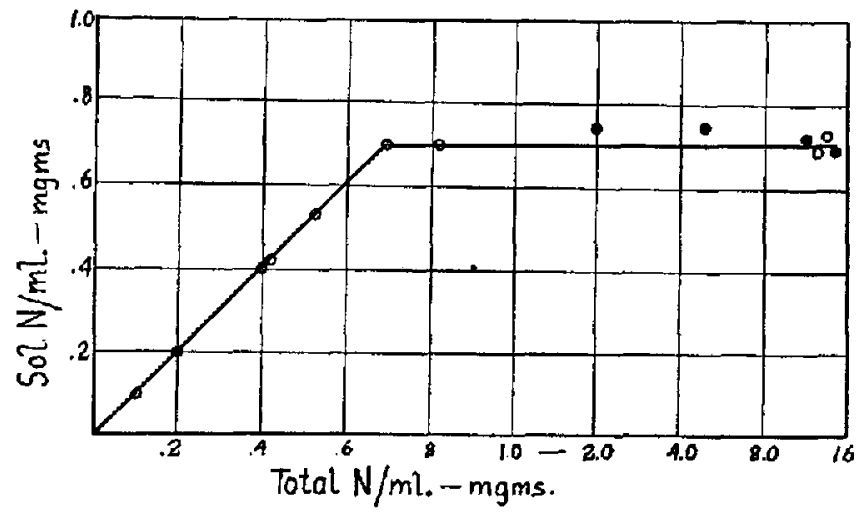

FIG. 6. Solubility of crystalline pepsin in 0.522 м sodium sulfate and $2.5 \times$ $10^{-5} \mathrm{~N}$ sulfuric acid at $20^{\circ} \mathrm{C}$.

TABLE VI

Ratio $\frac{\text { Activity }}{\text { Nitrogen }}=[\mathrm{PU}]_{\mathrm{gm} . \mathrm{N}}^{\text {gel. }} \mathrm{\textrm {N }}$

\begin{tabular}{|c|c|c|c|c|c|c|c|c|c|c|c|}
\hline \multirow{2}{*}{ 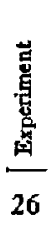 } & Pepsin & \multicolumn{7}{|c|}{ Solvent } & $\mid \begin{array}{c}\text { In pre- } \\
\text { cipitate } \\
\text { when } \\
\text { neariy } \\
\text { all } \\
\text { soluble }\end{array}$ & $\begin{array}{c}\text { In } \\
\text { solution } \\
\text { when } \\
\text { large } \\
\text { excess } \\
\text { of solid } \\
\text { present }\end{array}$ & $\begin{array}{c}\text { In original } \\
\text { crystals }\end{array}$ \\
\hline & Crystals & 0.05 & eta & $\mathrm{pH}$ & .65 & .50 & at. & $\mathrm{gSO}_{4}$ & 0.75 & 1.00 & \\
\hline 23 & " & " & " & " & " & " & " & $"$ & 1.2 & 1.11 & \\
\hline 22 & Amorphous & " & " & " & $"$ & " & " & " & 1.20 & 1.16 & \\
\hline 21 & " & 0.01 & “ & " & " & " & $a$ & $"$ & 1.09 & $\begin{array}{l}1.02 \\
1.13\end{array}$ & \\
\hline 20 & " & 4 & " & $"$ & ss & a & $"$ & " & 1.11 & 1.21 & \\
\hline
\end{tabular}

large excess of precipitate is the same within the experimental error as the ratio in the original material. The activity-nitrogen ratio of the 
first precipitate to appear is also the same in the experiments with amorphous and crystalline material as is shown in Table VI. If old preparations which have not been freed from the decomposition products are used, the activity-nitrogen ratio at this point will be low. An indication of this is shown in the first figure in thetableand in some of the figures.

The material is therefore either a pure substance or a solid solution the components of which have nearly the same solubility in all the solvents tried.

A summary of the solubilities in the various solvents is given in Table VII.

TABLE VII

Solubility of Pepsin

\begin{tabular}{|c|c|c|c|}
\hline Preparation & Solvent & $\begin{array}{l}\text { Tem- } \\
\text { perz- } \\
\text { ture }\end{array}$ & $\begin{array}{l}\text { Solu- } \\
\text { bility } \\
\text { N/mi. }\end{array}$ \\
\hline Crystals. & $0.522 \mathrm{M} \mathrm{Na}_{2} \mathrm{SO}_{4} 2.5 \times 10^{-5} \mathrm{~N}_{2} \mathrm{SO}_{4}$ & $20^{\circ}$ & $\begin{array}{c}3 \times 8 . \\
0.70\end{array}$ \\
\hline$" \quad \ldots$ & $0.444 \times \mathrm{Na}_{4} \mathrm{SO}_{4}, 0.0556$ acetate buffer $\mathrm{pH} 4.65$ & $20^{\circ}$ & .43 \\
\hline Amorphous... & 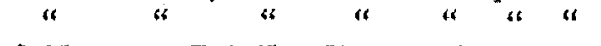 & $20^{\circ}$ & 2.2 \\
\hline Crystals.... & 0.05 acetate $\mathrm{pH} 4.65,0.50$ sat. $\mathrm{MgSO}_{4}$ & $8^{a}$ & .22 \\
\hline Amorphous. . & “ « " & $20^{\circ}$ & 1.00 \\
\hline & 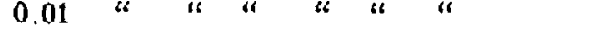 & $20^{\circ}$ & .65 \\
\hline
\end{tabular}

Inactivation.-It was pointed out by Pekelharing that the temperature coefficient for the inactivation of enzymes and especially of pepsin 
was extremely high and agreed with that for the denaturization of proteins. No other reaction known has such an enormous temperature coefficient and the agreement of the two values suggests that the enzymes are proteins. Pekelharing also showed that loss of activity in strong acid solution was accompanied by the appearance of denatured, insoluble protein. It can be shown that inactivation either by heat or by alkali is quantitatively proportional to the denaturization of the protein.

lnactivation by Alkali.-It is well known that pepsin is very sensitive to alkali. Goulding, Wasteneys and Borsook (13) showed that this inactivation could be separated into two reactions, one of which was instantaneous; and further that if the amount of this inactivation were plotted against the $\mathrm{pH}$ a titration curve with a $\mathrm{pK}$ of 6.85 was obtained. These experiments were repeated and the amount of inactivation compared with the amount of denatured protein found.

Experimental.-A series of 1 per cent solutions of the pepsin was made and adjusted to about $\mathrm{pH} 5$. Increasing amounts of alkali were then added to these solutions so as to give a series of solutions varying in $\mathrm{pH}$ from about 5.5 to 9 . An amount of acid equivalent to the amount of alkali in the tube, was added immediately after the addition of the alkali and the activity of the resulting solution determined after neutralization. $5 \mathrm{ml}$. portions were added to $5 \mathrm{ml}$. of a solution of half-saturated sodium sulfate and $\mathrm{m} / 500$ sulfuric acid. The unchanged pepsin is soluble under these conditions (to about 1 per cent) but the denatured protein is insoluble. The denatured protein therefore precipitates and the unchanged protein nitrogen is determined from the filtrate. In this way the percentage inactivation and percentage denaturization may be determined. The denatured protein is rapidly digested by the active enzyme so these solutions must be precipitated and fltered as soon as possible.

Control experiments with known mixtures of denatured and active pepsin show 
that very little activity is carried down with this precipitate if the activity is determined by hydrolysis of casein. If the activity is determined by hydrolysis of gelatin, however, the precipitate of denatured protein may be quite active; and this result is evidently due to the abnormal activity observed throughout in relation to gelatin hydrolysis. This complication may be avoided by determining the activity of the solution before precipitation.

The results of such an experiment are shown in Fig. 7. The inactivation of the pepsin is quantitatively parallel with the denaturization of the protein since the percentage of activity left is the same as the

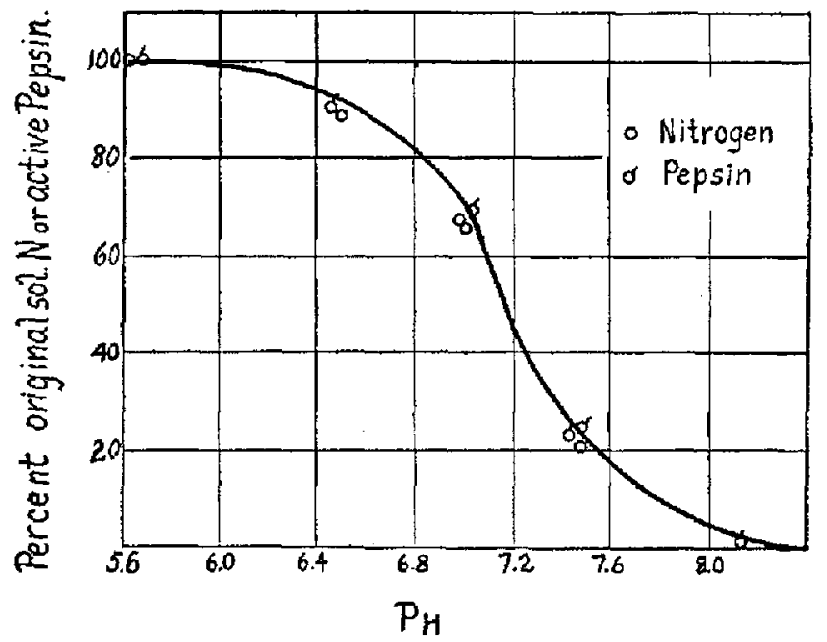

FIG. 7. Percentage inactivation and percentage denaturization of pepsin at various $\mathrm{pH}$ at $20^{\circ} \mathrm{C}$.

percentage of soluble nitrogen remaining. The curve is very similar to that of Wasteneys and Borsook but is a little more to the alkaline side.

Inactivation by Heat.-Pekelharing noted that when pepsin solutions were allowed to stand in a range of acidity where the pepsin is active, the protein was digested and at the same time the activity of the solution decreased. He concluded from this that the pepsin digested itself. It can easily be shown, as was mentioned above, that the denatured protein is rapidly digested and it seems probable that the effect noticed by Pekelharing was the result of denaturization of the protein followed by hydrolysis. It is then unnecessary to suppose that the enzyme di- 
gests itself. Pepsin solutions when heated slowly or when maintained at a temperature at which the inactivation proceeds slowly, do not contain denatured, insoluble protein since the latter is hydrolyzed as rapidly as it is formed. Under these conditions inactivation of pepsin is accompanied by the appearance of soluble nitrogen instead of insoluble; and it is difficult to make a sharp separation of the original pepsin from the products of hydrolysis. The result of an experiment which shows the digestion of denatured pepsin by active pepsin is given in Table VIII in which mixtures of various amounts of active and denatured pepsin were made up at $\mathrm{pH} 3$ and left at $35^{\circ} \mathrm{C}$. for 24 hours.

TABLE VIII

Digestion of Inactivated Pepsin $p H 3.0,35^{\circ} \mathrm{C}$.

Pepsin dissolved in $\mathrm{HCl}, \mathrm{pH} \mathbf{3 . 0}=$ Solution $\mathrm{A}$

$50 \mathrm{ml}$. A boiled, cooled = Solution D

$A$ and $D$ mixed in various proportions,

$2 \mathrm{ml}$. sample of mixture taken and

$2 \mathrm{ml} . \mathrm{M} / 1 \mathrm{Na}_{2} \mathrm{SO}_{4}$ added, filtered, $\mathrm{N} / \mathrm{ml}$. determined in filtrate.

\begin{tabular}{c|c|c|c|c}
\hline $\mathrm{A}$ & 20 & 10 & 5 & 0 \\
$\mathrm{D}$ & 0 & 10 & 15 & 20 \\
\hline Mg. soluble N in filtrate after: & & & \\
\hline 0 hrs. & .30 & .11 & .07 & 0 \\
$20 "$ & .30 & .30 & .28 & .01 \\
\hline
\end{tabular}

The denatured pepsin is precipitated by $\mathrm{m} / 1 \mathrm{Na}_{2} \mathrm{SO}_{4}$ at $\mathrm{pH} 3$, while the active pepsin is soluble. The table shows that the inactive and insoluble pepsin is dissolved by the active pepsin.

It may be shown, however, by means of solubility experiments, that the loss of inactivation in the solution is exactly paralleled by the disappearance of the original protein. If a saturated solution of pepsin in $\mathrm{M} / 300$ hydrochloric acid is placed at $65^{\circ} \mathrm{C}$. the activity is rapidly lost so that only about half the original activity remains after 15 minutes. No precipitate occurs but the formol titration increases. If the solution is now cooled and stirred again with a large quantity of crystalline pepsin more of the crystals must go into solution to 
replace the material which has been changed. If the inactivation of the enzyme is accompanied by some chemical change in the protein then the amount of material which will dissolve must be proportional to the percentage loss in activity. That is, if half the activity is lost the increase in solubility must be equal to half the original solubility (assuming the solubility to be unaffected by the presence of the inactivated enzyme). On the other hand, the activity per milliliter of the solution after being stirred with the solid should return to its original value. The result of an experiment designed to test this assumption is shown in Table IX. The solution was heated for 15 minutes at $65^{\circ} \mathrm{C}$. and in that time the activity per milliliter had been reduced to 50 per cent of its original value, whereas the formol titration

TABLE IX

Inactivated Pepsin and Solubility. $65^{\circ} \mathrm{C}$.

\begin{tabular}{|c|c|c|c|}
\hline & {$[\mathrm{PC}]_{\mathrm{ml}}^{\mathrm{gel}} \times \mathrm{X}^{\mathrm{s}}$} & $\mathrm{N} / \mathrm{mi}$. & Formol/ml. \\
\hline & & mg. & $\operatorname{mal} .0 .01 \mathrm{NaOB}$ \\
\hline $\begin{array}{l}\text { M/300 } \mathrm{HCl} \text {, stirred } 1 \mathrm{hr} \text { with pepsin, } 20^{\circ} \mathrm{C} \text {. } \\
\text { Centrifuge } \ldots \ldots \ldots \ldots \ldots \ldots \ldots\end{array}$ & 0.315 & 0.30 & 0.22 \\
\hline Supernatant heated at $65^{\circ} \mathrm{C}$. for $15 \mathrm{~min} . . .$. & .160 & .30 & .33 \\
\hline $\begin{array}{l}\text { Pepsin crystals added and stir } 1 \mathrm{hr} \text {, Cen- } \\
\text { trifuge }\end{array}$ & & & \\
\hline Observed ....................... & .325 & .45 & .45 \\
\hline Calculated $\ldots \ldots \ldots \ldots \ldots \ldots \ldots \ldots$ & .315 & .455 & .44 \\
\hline
\end{tabular}

had increased 50 per cent and the total $\mathrm{N}$ per milliliter was unchanged since no precipitate appeared. The solution was then cooled and stirred at $20^{\circ} \mathrm{C}$. with more crystals. The suspension was then filtered and the supernatant analyzed. The activity per milliliter is now the same as that of the original solution while the nitrogen per milliliter is 50 per cent higher than the original value. The formol titration has been increased by 50 per cent of its original value also. The results show that the loss of activity is exactly paralleled by some chemical change in the protein molecule.

The Rate of Inactivation at $65^{\circ} \mathrm{C}$.- It has frequently been found that the rate of inactivation of enzymes does not follow the course of a simple monomolecular reaction but becomes slower as the reaction 
proceeds. It was found by the writer (6) that this peculiarity was connected with the purity of the enzyme solution and that the rate of inactivation of more highly purified solutions agreed with the monomolecular reaction rate, while those solutions containing inhibiting substances did not. On this basis the rate of inactivation of the crystalline material would be expected to be monomolecular. The result of an experiment in which the rate of inactivation of a 0.06 per cent solution of pepsin in $0.001 \mathrm{M}$ hydrochloric acid $\left(\mathrm{pH} 3\right.$ ) at $65^{\circ} \mathrm{C}$. is shown in

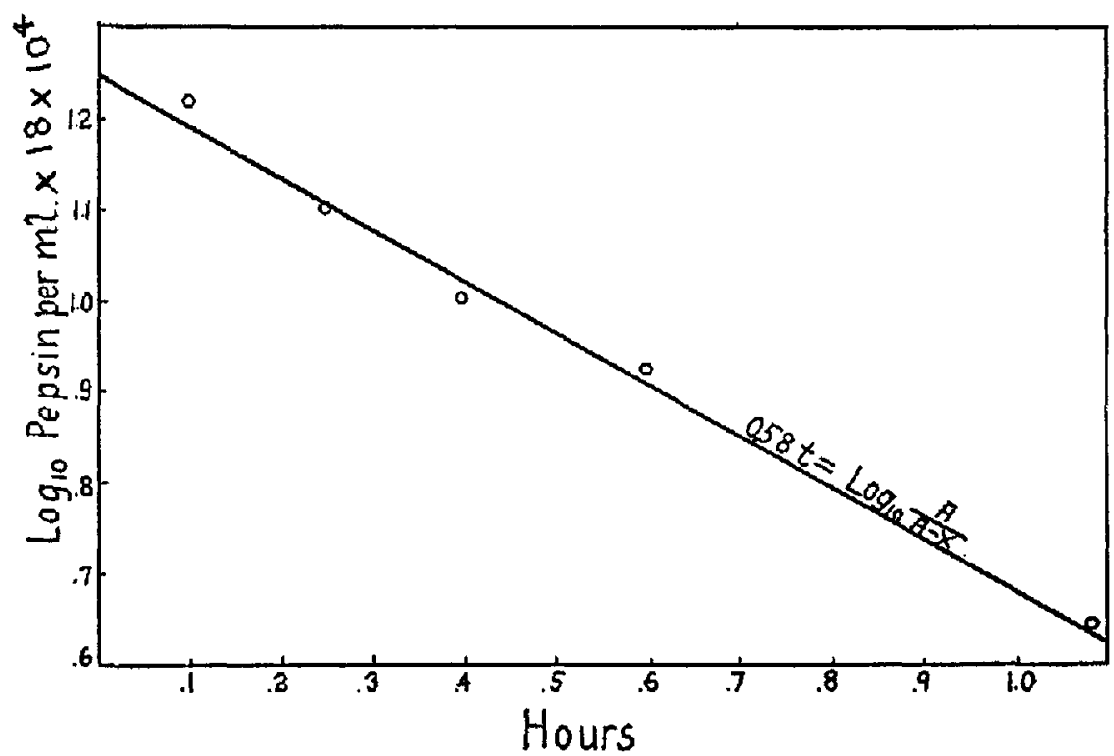

Fig. 8. Rate of inactivation of 0.06 per cent pepsin in $0.001 \mathrm{~m}$ hydrochloric acid at $65^{\circ} \mathrm{C}$.

Fig. 8. The reaction follows the theoretical monomolecular course quite closely.

Identity of the Diffusion Coefficient of the Protein and of the Active Material.-The preceding experiments have shown that the activity cannot be separated from the protein molecule either by solubility measurements or inactivation experiments. It might be assumed, however, that the crystalline substance was analogous to a double salt and that the active material and the protein were in equilibrium with each other but were separate in solution. If this were the case it would 
be expected that the rate of diffusion of the two would be different. The diffusion coefficients were therefore determined by the method previously described (14). The experiments were carried out at $8^{\circ} \mathrm{C}$. and the amount of material diffusing was determined by analyzing for nitrogen and also by activity determinations. The results of this experiment are shown in Table $\mathrm{X}$. The diffusion coefficient was found to be the same when determined by either nitrogen or by activity. The radius (and presumably the weight) of the molecule containing the nitrogen and of the active molecule must therefore be the same, so that there is no indication that the protein molecule is different from the molecule responsible for the activity even in solution. The diffusion coefficient is found to be $0.048 \pm 0.0005 \mathrm{~cm} .{ }^{2}$ per day which, according

TABLE $\mathrm{X}$

Diffusion Coefficient, Radius of Molecule and Molecular Weight

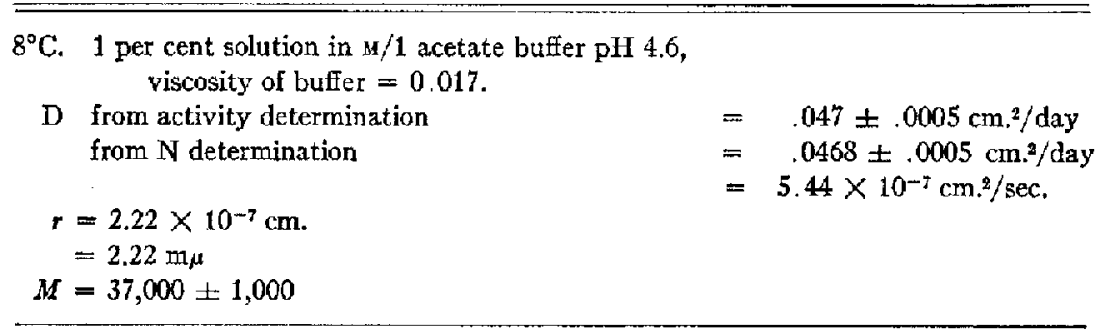

to Einstein's formula, gives a molecular weight of 36,000 . This figure agrees very well with the molecular weight of 37,000 as determined by osmotic pressure measurements. The agreement between these two figures shows that the molecules must be nearly all the same size since the molecular weight gives a mean value while the diffusion experiment as carried out gives a minimum value. The agreement also shows that the molecule is not hydrated to any great extent, since the value used for the specific gravity in calculating the molecular weight from the diffusion coefficient is the specific gravity of dry protein; and the value for the molecular weight so obtained agrees with that found by osmotic pressure. ${ }^{3}$

${ }^{3}$ Preliminary experiments (15) gave larger diffusion coefficients corresponding to a molecular weight of about 10,000 , but this result was found to be due to an error in calibrating the diffusion cell. 
Antipepsin.-If the enzyme is a protein an antibody should be formed on injection into an animal. The production of such antienzymes has been reported in the literature but the results are uncertain, as Euler has pointed out (16), because of lack of information in regard to the activity of the preparation used. In order to see if any antibody could be produced and if its production were associated with the activity of the preparation, two rabbits were immunized, one with an active preparation of the enzyme and one with a preparation of the same concentration which had been inactivated by alkali. $5 \mathrm{ml}$. injections of a 1 per cent solution of the active or inactive material were made intra-

TABLE XI

Antiserum

$1 \mathrm{ml} .1$ per cent pepsin solution in $\mathrm{m} / 54.6$ acetate buffer, diluted with buffer, $+0.15 \mathrm{ml}$. serum.

\begin{tabular}{|c|c|c|c|c|c|c|c|c|c|c|c|c|c|c|}
\hline \multicolumn{2}{|c|}{ Pepsin dilution } & -7 & - & 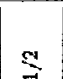 & 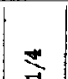 & $\stackrel{\infty}{=}$ & $\sum^{\infty}$ & है & 艺 & $\stackrel{\infty}{\stackrel{\infty}{*}}$ & 品 & 弪 & 悉 & $\begin{array}{l}8 \\
8\end{array}$ \\
\hline Pepsin & Serum & 0 serum & \multicolumn{12}{|c|}{$.15 \mathrm{ml}$ serum } \\
\hline Active & Active & - & & ++ & ++ & $+\div$ & ++ & + & + & + & + & + & + & +- \\
\hline “a & Denatured & - & ++ & $+t$ & $+t$ & +1 & + & - & - & - & - & - & - & -1 \\
\hline " & Normal & - & - & - & - & - & - & - & - & & & & & \\
\hline Denatured & Active & - & ++ & ++ & + & + & + & - & - & - & - & - & - & $-1-$ \\
\hline "6 & Denatured & - & ++ & ++ & +1 & + & - & - & - & - & - & - & - & -1 \\
\hline "6 & Normal & - & - & - & - & - & - & - & - & - & - & - & - & \\
\hline
\end{tabular}

peritoneally at intervals of about 1 week. Four injections were made; the rabbits were bled 2 weeks after the final injection and the serum obtained in the usual way. These sera gave a precipitin reaction with the pepsin solution, as shown in Table XI. Normal serum gave no precipitate with either the active or the inactive pepsin preparation. The serum obtained from the rabbit injected with active pepsingave a positive precipitin reaction in a dilution of about $1 / 2,000$ with the active pepsin solution and to about $1 / 16$ with the inactive solution. The serum from the rabbit immunized with denatured pepsin gave a precipitin test with the denatured preparation in a dilution of about $1 / 8$ per cent solution and with the active preparation to 
about the same extent. Both sera gave precipitin reactions with a 1 per cent solution of pepsin inactivated by boiling in a dilution of about 1/16. As might be expected, therefore, the sera were not strictly specific but gave cross precipitations with both active and denatured pepsin. The inhibiting effect of the sera on the activity was tested by mixing increasing amounts of the antiserum with a small amount of active pepsin and determining the rate of digestion of casein or gelatin with this mixture. The result of this experiment is shown in Table XII.

TABLE XII

Effect of Antiserum on Digestion of Casein or Gelatin by Pepsin

Serum diluted as noted $+\mathbf{m} / 54.6$ acetate buffer. Pepsin in 4.6 acetate buffer. $1 \mathrm{ml}$. pepsin solution $+1 \mathrm{ml}$. serum dilution.

\begin{tabular}{|c|c|c|c|c|c|c|}
\hline \multicolumn{7}{|c|}{ Gelatin } \\
\hline \multirow[b]{2}{*}{ Serum... } & \multicolumn{6}{|c|}{ Final dilution of serum } \\
\hline & $1 / 4$ & $1 / 8$ & $1 / 16$ & $1 / 32$ & $1 / 6$ & 0 \\
\hline & \multicolumn{6}{|c|}{$[\mathrm{PU}]_{\mathrm{ml}}^{\mathrm{gel} .} \cdot \mathrm{v}_{\text {after }} 3 \mathrm{hrs} . \times 10^{*}$} \\
\hline $\begin{array}{l}\text { Normal. } \ldots \ldots \ldots \ldots \ldots \ldots \ldots \ldots \ldots \ldots \ldots \\
\text { Antidenatured. } \ldots \ldots \ldots \ldots \ldots \ldots \ldots \ldots \ldots \ldots \ldots \\
\text { Antiactive. } \ldots \ldots \ldots \ldots \ldots \ldots \ldots \ldots \ldots\end{array}$ & $\begin{array}{r}0.075 \\
.060 \\
.045\end{array}$ & $\begin{array}{l}0.10 \\
.10 \\
.075\end{array}$ & $\begin{array}{r}0.11 \\
.09 \\
.10\end{array}$ & $\begin{array}{r}0.12 \\
.10 \\
.10\end{array}$ & $\begin{array}{r}0.1 \\
.1 \\
.1\end{array}$ & \begin{tabular}{l|r}
1 & 0.12 \\
1 & .12 \\
1 & .12
\end{tabular} \\
\hline \multicolumn{7}{|c|}{ Casein } \\
\hline 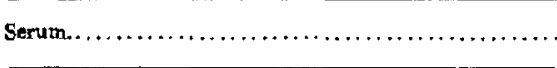 & 0 & & Normal & denat & & Antiactive \\
\hline 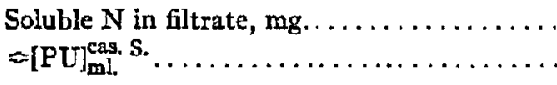 & $\begin{array}{r}2.2 \\
.01\end{array}$ & & $\begin{array}{l}2.0 \\
.008\end{array}$ & $\begin{array}{r}1.8 \\
.0\end{array}$ & & $\begin{array}{r}1.87 \\
.007\end{array}$ \\
\hline
\end{tabular}

Both the serum prepared by the injection of the active pepsin and that prepared by the injection of the denatured pepsin inhibit the action of the enzyme to about the same extent when tested by the solution of casein (cas. S. method). The normal serum inactivates somewhat less although there is no very great difference. It is difficult. to compare the action of the various sera quantitatively from this experiment. The effect may be seen more clearly by determining the rate of hydrolysis of gelatin (gel. V. method) with a small amount of 
pepsin to which has been added increasing amounts of the various sera. The result of such an experiment is also shown in Table XII. The active serum inhibits quite strongly in a dilution of $1: 4$, the denatured serum less so and the normal serum still less. This inhibiting effect is evidently very weak compared with that of many antitoxins, although the precipitin reaction is about what would be expected. This may be due to the fact that the pepsin injected must be almost instantly inactivated since, as was shown above, the pepsin is instantlymore than half inactivated at a $\mathrm{pH}$ of 7 . It is probable therefore that the active pepsin is in the circulation of the animal for only a very short time.

The writer is indebted to Dr. F. S. Jones and Dr. A. P. Krueger for advice and assistance in connection with these experiments.

VI

\section{Conctusions as to the Purity of the Preparation}

The preceding experiments have shown that no evidence for the existence of a mixture of active and inactive material in the crystals could be obtained by recrystallization, solubility determinations in a series of solvents, inactivation by either heat or alkali, or by the rate of diffusion. It is reasonable to conclude therefore that the material is either a pure substance or a solid solution of two very closely related substances. If it is a solid solution of two or more substances it must be further assumed that these substances have about the same degree of solubility in the various solvents used, as well as the same diffusion coefficient and rate of inactivation or denaturization by heat. It must also be assumed that both substances are changed by alkali at the same rate and to the same extent. This could hardly be true with the possible exception of two closely related proteins. It is conceivable that two proteins might be indistinguishable by any of the tests applied in this work. But in this case it would follow that the enzyme itself was a protein and this, after all, is the main point. It does not necessarily follow even if the material represents the pure enzyme that it is the most active preparation that can be obtained nor that it is the only compound which has proteolytic activity. There is some evidence that the activity of the preparation may depend on its physical state as is known to be the case with the catalytic activity of 
colloidal metals. It is possible, on the other hand, that hemoglobin is the type structure for the enzymes and that they consist of an active group combined with a protein as suggested by Pekelharing. The active group may be too unstable to exist alone, but it is quite conceivable that a series of compounds may exist containing varying numbers of active groups combined with the protein, and that the activity of the compound would depend on the number of these active groups. This hypothetical complex would not differ much from that assumed by Willstätter (18) and his coworkers, except that it supposes a definite chemical compound with the protective group in place of an adsorption complex. It is of course possible that both types of complex may be formed under suitable conditions. The reactivation of enzymes as reported in the literature also suggests their protein nature since the conditions for this reactivation are similar to those found by Anson and Mirsky (20) to be suitable for the formation of native from denatured protein. The fact that the crystalline urease prepared by Sumner is also a protein and that the temperature coefficient for the rate of inactivation of enzymes in general is that characteristic for the denaturization of proteins, suggests that the protein fraction in the purification of enzymes be given special attention even though it may not be the most active fraction.

The crystalline pepsin resembles the amorphous preparations obtained previously by Pekelharing, Ringer, Fenger, Andrew and Ralston and other workers. It is probable that the preparations obtained by these workers were nearly pure pepsin. Both Pekelharing and Ringer (17) obtained preparations free from phosphorus so that there may be several proteolytically active forms.

Pekelharing showed that the same protein material could be obtained from gastric juice as from autolyzed gastric mucosa so that it is probable that the crystalline material could also be readily prepared from gastric juice. It seems fair to conclude therefore that the crystalline protein described in this paper is identical with the enzyme pepsin as secreted by the animal. 
VII

\section{Proteolysis Is a Homogeneous Reaction}

Sørensen has shown that a solution of egg albumin is a one-phase system and the solubility measurements described in this paper show that a solution of pepsin consists also of only one phase. The reaction between dissolved egg albumin and dissolved pepsin therefore is a case of homogeneous, rather than heterogeneous catalysis.

\section{SUMMARY}

A method is described for the preparation of a crystalline protein from commercial pepsin preparations which has powerful peptic activity. The composition, optical activity, and proteolytic activity of this protein remain constant through seven successive crystallizations. No evidence for the presence of a mixture or of a solid solution is found in a study of the solubility of the protein in a series of different salt solutions, nor from the diffusion coefficient or from the rate of inactivation. These results indicate that the material is a pure substance or passibly a solid solution of two or more substances having nearly the same solubility in all the various solvents studied. It seems reasonable to conclude from these experiments that the possibility of a mixture must be limited to a mixture of proteins, so that the conclusion seems justified that pepsin itself is a protein.

\section{BIBLIOGRAPHY}

1. Sumner, J. B., J. Biol. Chem., 1926, 69, 435.

2. Cf. Taylor, H. S., Treatise on physical chemistry, Van Nostrand, New York, $1925,2,956$.

3. Fodor, A., Grundlagen der dispersoidchemie Steinkopfi, Dresden, 1925.

4. Kuhn, R., and Wasserman, A., Ber., 1928, 61 B, 1550.

5. Vernon, H. M., J. Physial., 1904, 30, 330.

6. Northrop, J, H., J. Gen. Physiol, 1922, 4, 261.

7. Marston, H. R., Biochem. J., 1923, 17, 851.

8. Pekelharing, C. A., Z. Physiol. Chem., 1896, 22, 233.

9. Fenger, F., Andrew, R. H., and Ralston, A. W., J. Biol. Chem., 1928, 80, 187.

10. Northrop, J. H., J. Gen. Physiol., 1930, 13, 781.

11. Anson, M. L., Unpublished results.

12. Cf. Taylor, H. S., Colloid Symposium Monograph, 1926, 4, 19.

13. Goulding, A. M., Wasteneys, H., and Borsook, H., J. Gen. Physiol., 1926-27, 10,451 . 
14. Northrop, J. H., and Anson, M. L., J. Gen. Physiol., 1929, 12, 543.

15. Northrop, J. H., Science, 1929, 69, 580.

16. Euler, H., Chemie der enzyme, Bergmann, München, 3rd edition, 1925, Part 1, 390 .

17. Ringer, W. A., Z. physik. Chem., 1915, 95, 195.

18. Willstätter, R., Naturwissenschaften, 1927, 15, 585.

19. Northrop, J. H., J. Gen. Physiol., 1926, 9, 767.

20. Anson, M. L., and Mirsky, A. E., J. Gen. Physiol., 1929, 13, 121. 